\title{
Article
}

\section{People die in six ways and each is politics: Infrastructure and the possible}

\author{
J. Mohorčich \\ Lehman College, City University of New York, Bronx, NY 10468, USA. \\ joseph.mohorcich@lehman.cuny.edu
}

\begin{abstract}
Critical infrastructure services determine where people can survive and what they can do with their survival. This fact conditions political possibilities at a fundamental level but remains underexplored in the literature. Those who wish to extend the boundaries of political action, or to win protections and the possibility of a new political community for themselves and others, should focus a substantial part of their energies and attention on developing alternative infrastructure systems for supporting human life. Without such systems, political action - no matter how revolutionary or ingenious - will ultimately find itself constrained by its position within the zones of survivability established by existing forms of infrastructure and by the hierarchies and configurations of power linked with those forms of infrastructure. As a result, those who wish to change current political and economic conditions should think of the capacity to take care of everyone as a condition for such change rather than its result.

Contemporary Political Theory (2022) 21, 175-197. https://doi.org/10.1057/s41296021-00518-5; advance online publication 3 September 2021
\end{abstract}

Keywords: Infrastructure; Revolution; Autonomy; Resistance; Life support

People mostly die in six ways: heat, cold, hunger, thirst, illness, and injury (Gupta, 2013). Human beings have constructed enormous technical and social systems to protect themselves from dying of these causes. We call the physical components of these systems 'infrastructure': the edifice beneath. Infrastructure delimits where human beings can go and what they can do. A person will live to 84, on average, in Hiroshima, Japan, but to 54, on average, in Sokoto, Nigeria, because the edifices protecting humans from the six ways to die are stronger and more extensive in Hiroshima.

The practice of developing critical infrastructure to stay alive has been perhaps the most consequential and continuous project that humans have undertaken. This campaign, which is really many overlapping campaigns, has introduced a number of political complications, not all of which have been fully explored. For one,

(C) 2021 The Author(s), under exclusive licence to Springer Nature Limited. 1470-8914 Contemporary Political Theory Vol. 21, 2, 175-197

www.palgrave.com/journals 
humans have often built infrastructure for things other than survival, including projects that make people more likely rather than less likely to die. For another, even wildly beneficial infrastructure projects, like improving irrigation or fertilization to extend growing seasons or increase crop yields, can trigger negative effects by creating the conditions for heightened exploitation of the environment and of humans and other animals. Additionally, life-support infrastructure can protect not only against the natural absence of resources for maintaining life, but also against human interventions that threaten life. Consider the difference between using a filtration system on a natural water source in order to make it potable and filtering a water source that has been spoiled by agricultural runoff. Or the difference between constructing a shelter against cold and erecting a barrier against police incursion. As human actions inflict deeper and more extensive changes on the planet and increasingly threaten the ways that humans stay alive, life-support infrastructure becomes less an intervention humans make into or against the natural world and more a counterintervention directed at other human action. Finally and relatedly, the extent to which humans in a specific area are dependent on local infrastructure systems in order not to die determines in large part the degree to which they are held in thrall by the people or institutions who control the means of not dying in that area.

The power flowing from infrastructure is unique for at least five reasons: it is nearly invisible until it is exercised, it is administered by people who are rarely elected or considered particularly notable within government, it usually dominates other forms of power where they conflict with it (it is difficult to coerce a population with an army you cannot feed), it touches every area of life, and, because it has to do with ordinary needs that can be satisfied many ways, it is susceptible to counterpower built against it through means that do not themselves appear to have much to do with political power or coercion. (This final point will become important for this analysis.) Because of these and other features, the power the flows from critical infrastructure services tends to be at once potent, extensive, and overlooked. As Gupta (2013) argues, 'When you turn on the heat in winter, you're turning on this service that's directly connected to the structure of global capitalism', a structure that is 'maintained largely by the force of the American government, and to some degree the Europeans and the Chinese, and then their intelligence services'. Gupta suggests that 'It's the closing of the loop between the provision of critical infrastructure and the need for defense and security service... that's the core tension' that locks out the possibility of deep-seated social and political change. The stubborn and fundamental facts are that a variety of the systems that keep humans alive (i) themselves constitute systems of violence and oppression and (ii) are interlinked with political systems that engage in violence and oppression.

And so: critical infrastructure services determine where people can survive and what they can do with their survival. This fact conditions political possibilities at a 
fundamental level but remains underexplored. The link between infrastructure and violence is not an eternal and immutable fact of physical reality. Because critical infrastructure systems are a way of satisfying basic human needs, alternative ways of meeting these needs can be constructed that are less amenable to hierarchical control and coercion both by design (e.g. certain forms of decentralization or distributed trust) and by choice (e.g. the mission of the people building a certain system is to take care of everyone rather than, say, to serve the state, to turn a profit, or to have no mission at all, which opens avenues for cooptation). Those who wish to extend the boundaries of political action, or to win protections and the possibility of a new political community for themselves and others, should focus a substantial part of their energies and attention on developing alternative infrastructure systems for supporting human life and activities. Without such systems, political action - no matter how revolutionary or ingenious - will ultimately find itself constrained by its position within intersecting zones of survivability established by existing forms of infrastructure and by the hierarchies and configurations of power linked with those forms of infrastructure. As a result, those who wish to change current political and economic conditions should think of the capacity to take care of everyone as a condition for such change rather than its result.

To understand the importance of constructing alternative infrastructure stacks, I wish to discuss first certain historical interventions in critical infrastructure systems.

\section{Critical infrastructure and its histories}

In August 1854, the inhabitants of London began, once again, to die of cholera. The volume of dead increased so quickly that bodies were stacked beneath churches and dumped into sewers. The city had long lived in fear of cholera's return: the epidemic of 1848-49 had killed between 54,000 and 62,000 Londoners from a population of $\sim 2.9$ million (a mortality rate roughly an order of magnitude higher than London's during its 2020-21 waves of COVID-19). Through painstaking interviews, water sampling, and legwork, a physician named John Snow constructed a map of the cholera deaths in Soho (Figure 1).

Gradually, Snow became more convinced that cholera did not come from 'bad air', as miasma theory suggested. Instead, he began to suspect that London's water was the primary conduit for the disease. Snow, via days of interviews and tracing drinking water delivery, identified one public water pump, on Broad Street, as the center of the outbreak. 'Snow had built a convincing statistical case against the pump', Johnson (2006) writes. 'Of the eighty-three deaths recorded [by one source], seventy-three were in houses that were closer to the Broad Street pump than to any other public water source. Of those seventy-three, Snow had learned, sixty-one were habitual drinkers of the Broad Street water... Snow had established

(C) 2021 The Author(s), under exclusive licence to Springer Nature Limited. 1470-8914 Contemporary 177 Political Theory Vol. 21, 2, 175-197 


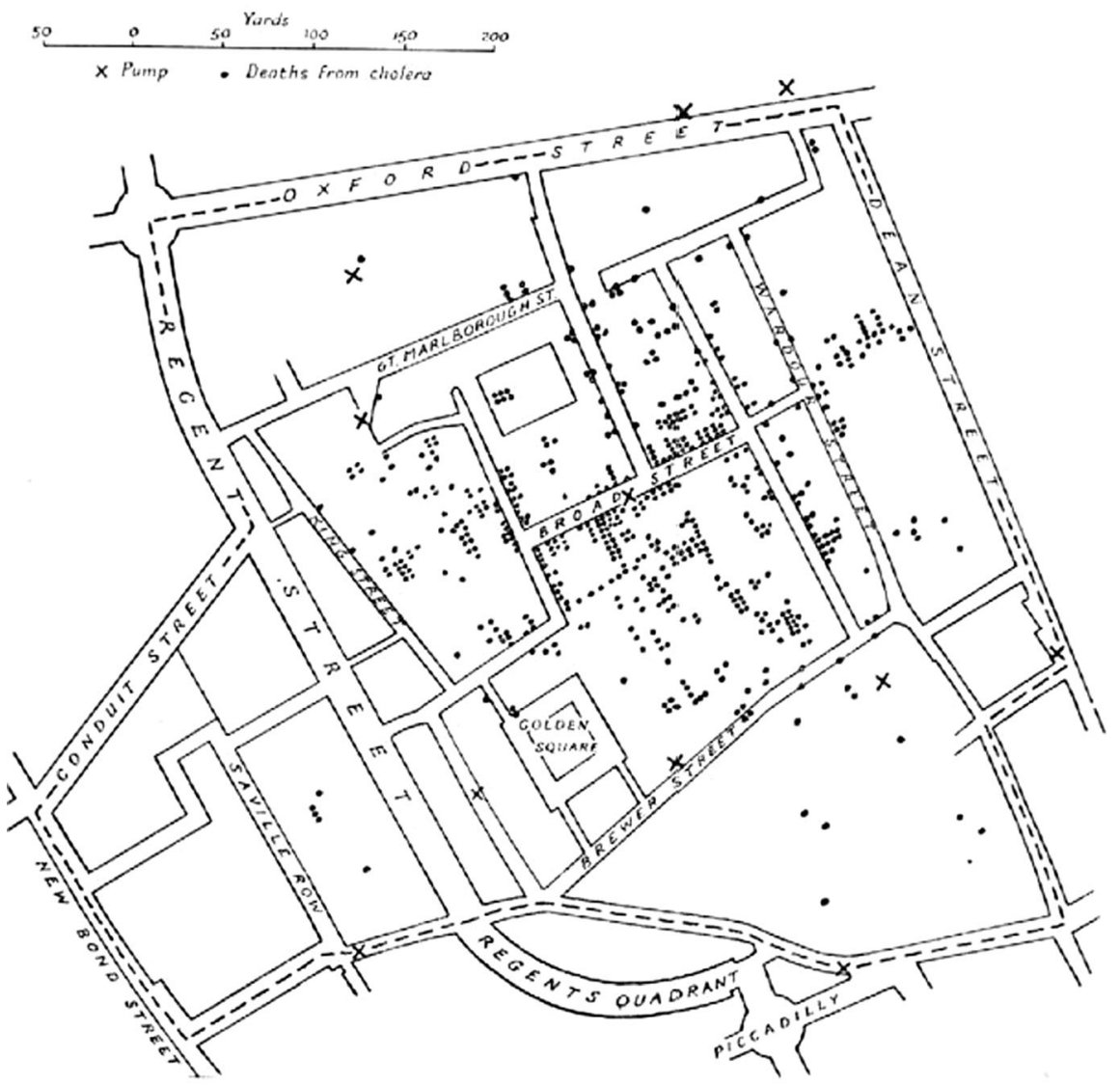

Figure 1: John Snow's 'ghost map'. The central X, denoting the contaminated Broad Street pump, is surrounded by dots that mark deaths.

new causal chains back to the pump water'. Snow presented his case to the Board of Governors and Directors of St. James Parish, who - though skeptical - ordered the Broad Street pump handle to be removed. Cases subsided.

By examining how a person in Soho retrieved drinking water every morning, Snow was able to understand how minor but deeply-set infrastructural features - in this case, a porous barrier between a private cesspool and the Broad Street pump well - altered the historical, political, and public health trajectories of London. Snow's central insight, so obvious in hindsight it is easy to underestimate, was to trace a thread of causation from a one-meter iron pump handle across interlocking layers of material, technical, social, and biological systems to the $V$. cholerae bacteria in the small intestines of Londoners. By making this link, Snow opened new possibility 
spaces not only in the fields of epidemiology and data science, but also for those who wish to focus political energies on critical infrastructure systems.

In political theory, questions of survival and infrastructure have emerged in a general and moderately disguised form as part of the environmental political theory literature. For example, work by Barry (2012), Vanderheiden (2008a, 2008b), and Symons and Karlsson (2015) have raised questions of survival within the context of the failures of contemporary political systems to respond to climate change. Lane (2016) offers a fuller analysis of the tradition that these texts operate within when she traces political theory's relationship to climate change from 2005 to 2015. She points out that one underutilized role for political theory in climate change discussions is to interrogate the connection between expertise and democracy how, for one, are objects of scientific understanding translated into political objects, and how are these objects taken up by (and restructure in turn) political processes? Mitchell (2011) has worked on one version of this sort of interrogation. He writes about how the infrastructural realities of energy production, especially of coal and oil, have conditioned political life in the countries that undertake such production, although his work touches human survival only indirectly.

MacArthur and Matthewman (2018) have, in a paper that is closer to this article, described how Māori tribal ownership of geothermal heat and power infrastructure reshapes the political and climatological landscape in New Zealand. They find that there is no substitute for direct control of physical resources and infrastructure, and that ideational shifts around interconnectedness and survivability are most powerful when they can be channeled through built life-support services. Work by Bennett (2010) and, in anthropology, Anand et al. (2018) and Larkin (2013) has called attention to the liveliness and agency of infrastructure systems, albeit with a focus on these systems' temporal, affective, and agentic dimensions rather than their direct impacts on and realization of human survival. Schmidt has worked on connecting the new materialism and the decentering of the human to climate change mitigation literature (Schmidt, 2013). Much of the work on infrastructure and survival that does exist has come from literatures adjacent to political theory. The anthropologist Boyer (2018) and geographer Amin (2013), for example, stress the revolutionary potential of infrastructure and its relation to human survival, although they do not explicitly describe the relationship between infrastructure space and the prospect of radical political change. (Boyer and Amin are not political scientists, so this can be held against them only gently.)

In sociology, Simone $(2004,2015)$ has described the mutual cohabitation - cities in people, people in cities - that infrastructure space realizes and the way that the residents of Johannesburg's inner city neighborhoods constitute a moving infrastructure for one another. These human networks form a powerful kind of life-support net that is more fluid than - but also partially reliant upon conventional infrastructure. Klinenberg (1999), conducting earlier work in this vein, describes the relationship between physical infrastructure and social ties as a

(c) 2021 The Author(s), under exclusive licence to Springer Nature Limited. 1470-8914 Contemporary 179 Political Theory Vol. 21, 2, 175-197 
way of explaining who lived and died during the July 1995 heatwave in Chicago's North and South Lawndale neighborhoods. (For work discussing Klinenberg, the heatwave, and Klinenberg's potential deployment of the 'ecological fallacy', see Duneier, 2006). Both Simone and Klinenberg emphasize the capacity of humans and social ties to act as a kind of infrastructure unto themselves. Addie (2021) extends this line of thinking when he, relying in part on Simone, points out that human social ties and labor are embodied - or entombed - within existing critical infrastructure. Moreover, this infrastructure does not broadly and equally support everyone. It sustains life only for some. Addie's work continues an ongoing discussion of the necropolitics of infrastructure: the ways that capitalist and colonial infrastructure systems do not provide life support for all people, but can in fact narrow conditions for survival for marginalized or subaltern groups. Pasternak and Dafnos (2018) argue that settler states have used terms like 'critical infrastructure' and the securitization of infrastructure to further entrench and defend structures of capital accumulation. This process can take the form, for example, of criminalizing of those who oppose new pipeline construction as threats to national security, energy independence, or the 'supply chains of capital' (Pasternak and Dafnos, 2018).

Pasternak and Dafnos' work raises the question of how academically familiar ways of conceptualizing or schematizing violence, like capitalism, settler colonialism, austerity, or neoliberalism, relate to specific inquiries around heat, hunger, injury, and illness. These two levels of inquiry are not at odds but rather can be used to complicate one another. For example, De Coss-Corzo (2021) documents how patchwork repairs and workarounds allow SACMEX, Mexico City's water authority, to continue delivering water to the city's inhabitants in the face of austerity, disinvestment, and decay. De Coss-Corzo's work shows how securing basic infrastructural supports for human life often demands operating with one foot inside and one outside state structures of power and support. When SACMEX workers invent on-the-fly workarounds for busted water mains, they both extend and undermine state delivery of water in Mexico City. They extend such delivery by allowing the current system to continue to keep people alive, but they undermine it by building knowledge, tools, and procedures for maintaining a water system beyond the limits of state authority and support. That is, SACMEX workers maintain the system while generating the means for its future supplement or replacement.

Finally - and speaking of extrastatecraft - the work by Easterling, Bratton, Gupta, and Springett discussed in this article remains adjacent to political theory but splits open questions of how infrastructure shapes what is possible within politics. Arguments from these authors, Gupta in particular, have become central to this article in large part because, whatever their other concerns, their work returns to what is material to human survival: the fact that humans need potable water, food, shelter, and care to not die. 
These interdisciplinary literatures notwithstanding, political theory's treatment of infrastructure's relationship to the political often takes the form of accurate but familiar statements that infrastructure is never neutral but is irreducibly, inherently, or always-already political (McFarlane and Rutherford, 2008). Often, work in political theory that is concerned about the health or livability of the natural world treats, understandably enough, the natural world as a new site of digestion for political science, a territory to be duly processed as always and already political. This intellectual reflex can be seen, for example, in the slotting of environmental inquiry alongside or within existing concerns around distributive justice, violence, autonomy, deliberative democracy, and so on (Eckersley, 2004; Schlosberg, 2005; Salleh et al., 2017). I argue that the conditions for survival established among human beings and between humans and their environment bind politics as a historical fact and as an ongoing concern. The term 'environmental' in environmental political theory is conditioned from the outset by what is possible within the domain of survival. Many scholars would rightly say that they are trying to think a theory and environment, a politics and environment, as terms or processes that mutually constitute one another. It is one thing to claim mutual constitution in the familiar parlance of theory and another to say how specifically such terms are constituted mutually, beyond their association in academic texts. The answer this article gives to the 'how specifically is what you say true?' question is straightforward: the mutual tie between environment and theory as well as between environment and politics is established by the fact that organisms of sufficient complexity to do politics must establish some means of survival within an environment or there will be no politics. Moreover, this fact is true across time, which is a way of saying it is not only a historical observation but also a going concern: all that is political - thought, organization, action - continues to be conditioned by the fact of its occurrence inside and reliance upon infrastructure's zones and platforms of livability.

Efforts to study critical infrastructure and its conditioning of politics can be found moving in and out of labels like critical infrastructure studies, extrastatecraft, and stacktivism (Larkin, 2013; Springett, 2013; Amin, 2014; Easterling, 2014; Anand, 2017), but have remained mostly outside the remit of political theory, despite a turn to infrastructure in fields like geography and urban studies (Dodson, 2017; Addie et al., 2020). These labels connote different varieties of interest in political action centered on the infrastructural supports that make possible specific political, social, and material realities. One common term of art is that of a 'stack', which denotes the interlocking pillar of technologies upon which a person's lifestyle is built. When Bratton, for example, writes about 'the stack', he describes the levels of technology that make global computing possible as a vertically-arranged, 'modular, interdependent... multilayered structure' that includes 'infrastructure at the continental 
scale, pervasive computing at the urban scale, and ambient interfaces at the perceptual scale' (Bratton, 2015) (Figure 2).

Terms like 'assemblage' or 'technosocial system' are of course related to the notion of stacks. I primarily use the language of technology stacks because the term is specific and spatial: it connotes verticality, the importance of different interacting layers, the way that technical and social systems supervene on other, less-visible structures, and the way that risks, vulnerabilities, and changes can propagate up and down a chain of intergrown systems. A first task for anyone interested in intervening in or building alternatives to present infrastructure systems is to describe how critical services like food, water, energy, shelter, medical care, and communication emerge from technology stacks, to map how the components of these stacks are arranged vertically (how much of the Salar de Atacama salt flats reside inside your house in the form of lithium-ion batteries?) and how these stacks are interleaved with one another (delivering heat and desalinating water may both rely on the same power delivery system). The answers to these questions illuminate where infrastructure stacks' interdependencies lead to shared points of failure and how existing systems for life support can be reformatted or made redundant.

Consider the link between the power supplied to a laptop in Baltimore, Maryland, and macrophage activity in the lungs of miners in southwestern Pennsylvania. If you lived in Maryland in the late 2010s, about 44\% of your electricity came from burning coal to produce steam to spin turbines. Much of the coal that feeds the city of Baltimore is mined in Greene County, Pennsylvania, at the Bailey Mine Complex, barged to Anne Arundel County, and burned at the Brandon Shores Generating Station to produce steam to produce electricity (US EIA, 2016). Electrons run from Brandon Shores through aluminum-conductor steel-reinforced cables into Baltimore's rowhouses and apartments. From 2000 to 2009 , the age-adjusted death rate from coal workers' pneumoconiosis in Greene

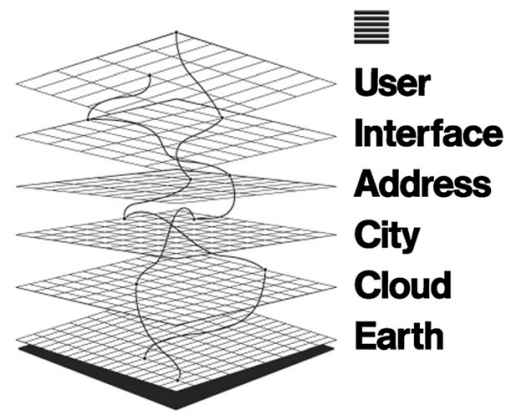

Figure 2: 'Diagram by Metahaven of the six layers of The Stack'. See Bratton (2015). This simple scheme represents the stack that supports cloud computing. Other technology stacks make possible the delivery of fluoridated water in cities or heat buildings in winter, and these life-support stacks interleave like decks of cards partially shuffled into one another. 
County, PA, was thirty times higher ( 87.7 per million) than the base rate $(2.9$ per million) in the United States (NIOSH, 2014).

Thinking about the stack of technologies that makes your lifestyle possible imbues political and ethical questions with a new literalism. Because critical infrastructure services establish the conditions of possibility for political action, one powerful form of analysis involves approaching a political problem literally as a question of survival, that is, in terms of the components that sustain or fail to sustain the safety and wellbeing of the people involved. Recall that the Black Panther Party's examination of questions of survival in the 1960s and '70s led to their creation of the Survival Programs, the most famous of which was the Free Breakfast for School Children Program, which fed thousands of children in dozens of cities in the United States in the 1970s. The Panthers' Survival Programs also included busing to and from prisons, ambulance services, 'medical self-defense', free clothing and housing, plumbing and maintenance services, pest control, and manufacturing shoes (Jones, 1998). (A year later, another alternative system for survival was established in Hayward, CA, by a group of local women: Emergency Shelter Program Inc., or the first women's shelter in the US.)

Most human deaths, as noted earlier, fall into six categories: too hot, too cold, hunger, thirst, illness, or injury (Gupta, 2010a). Groups of humans have developed different life-support systems for delaying the time at which they will die from one of these causes. This is true at every scale, from a single human building a shelter in the woods to workers clocking in at the Brandon Shores Generating Station to the shackle hoist operator at a slaughterhouse. It is possible to map the operational scales of different life support systems with simple critical infrastructure maps, or SCIMs, like this one (Figure 3):

The life-support systems that make human societies possible are the product of political struggles informed by decisions about who is entitled to life and who is not. This means that building alternative infrastructures or altering existing infrastructure systems offer powerful levers for political and change that extend from the material realities of how humans in a specific polity live and die. 'One of the things the Luddites understood', as Springett writes, 'was that certain technologies internalize certain ideologies' (Springett, 2015). The stacks of interlocking technologies that make human life possible also represent the terrain of current and future political struggles, and their making and unmaking of human life is itself a site of justice and injustice subject to political contestation. As Easterling argues, infrastructure systems have 'often been groomed as either an instrument of militarism, liberalism, or universal rationalization', but unassuming histories about 'the growth of international organizations, the division of the radio spectrum, or the creation of the satellite, fiber-optic, and mobile telephony networks' can carry unexpected political consequence (Easterling, 2014). Easterling urges a technically-informed, 'less self-congratulatory [or] automatically oppositional, but potentially effective and sneakier set of techniques' for political

(c) 2021 The Author(s), under exclusive licence to Springer Nature Limited. 1470-8914 Contemporary 183 Political Theory Vol. 21, 2, 175-197 


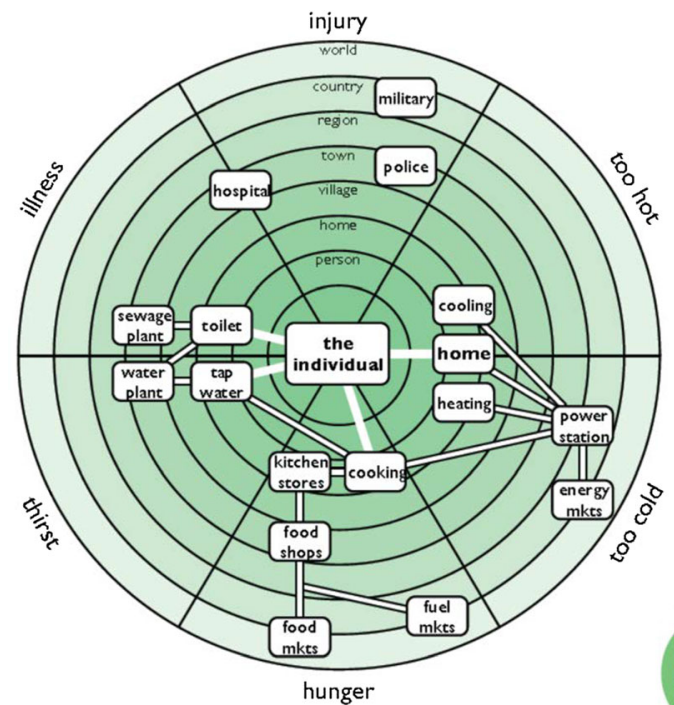

SCIM

Figure 3: A simple critical infrastructure map. This SCIM 'shows how a typical western individual is protected from the six ways to die by the layers of infrastructure'. See Gupta (2010a, b).

action, including 'exaggerated compliance, gossip, rumors, remote controls... [an] extended repertoire of form-making that's both more elusive and powerful'. Because these techniques draw their effectiveness from the reservoirs and structures of power already present in political and infrastructural networks, the components of these networks do not automatically constitute barriers. In many instances, extant technical systems offer 'a means to amplify or leverage or exploit... Not tense binaries of resistance, but release into a new territory' (Easterling, 2012). Mapping the existing political and infrastructural terrain merely as a field of obstacles limits the scope and effectiveness of efforts to alter that terrain.

As a practical matter, the systems that allow you to maintain the blood sugar and hydration levels that make possible forms of protest or chapters for an edited volume are as constitutive of political action as the ideational drivers and stakes of those actions. Consider the fact that any academic living in Baltimore or New York could drive to West Virginia, purchase AR-15s, M107s, and other weapons, and form an armed cell in the Blue Ridge Mountains outside of Washington, D.C. But the outcome of such a choice would never be in doubt: even if the would-be armed cell-ists weren't detained or killed by Virginia State Police tactical response units, they would face starvation and exposure. There would be no reliable way to get a cell signal, medical supplies, or potable water. It is, as Gupta argues, the 'closing of the loop between the provision of critical infrastructure and the need for defense 
and security service [that is] the core tension of why we can't make progress against these forces'. Armed revolution may seem like an edge case, but these same facts structure political work that does not involve forming armed cells. Arrangements of critical infrastructure and the balance of physical power hold true while grocery shopping or feeding schoolchildren in Oakland or building new telecommunications networks in South Africa. If you were to read widely in contemporary political theory and activist literature, you might come away thinking that the limits of political action are set by what is thinkable, by conceptual modes and models. To be sure, epistemes and structures of perception and counterperception matter a great deal, and conceptual work and material structures are mutually embedded within one another. But as a matter of fact, the limits of political action are set by what is possible within the zones created by infrastructure. Few things better define the position of the contemporary academic-activist than being metabolically dependent on far-reaching, militarilydefended structures of global capitalism while at the same time undertaking the labor of reconfiguring or undermining those structures on cultural and intellectual terrain. It is crucial to avoid the hypocrisy trap (e.g. "you claim to be an anticapitalist but you buy food at a grocery store') and to recognize the omnipresence of critical service questions and to account for the infrastructural components of the problem of political transformation. Like sacrifices before a distant god, cultural and textual criticism have been leveraged against a problem that is about avoiding cholera outbreaks before, or at least alongside, it is about fine-tuning the critique of the critique of a given social and economic system. Undoing the ouroboros wherein scholars and activists agitate against depredation and degradation while being within the securitized metabolic loop that engenders that same depredation and degradation involves, as Gupta (2013) puts it, 'get[ting] into a position where we're no longer dependent... on the standing means of political oppression for our basic survival needs'.

But how is this possible, and where do you start?

\section{Taking care of everyone is a condition for revolution rather than its result}

Analyzing who controls the means of survival derives its political salience from the facts that (i) everyone can die, (ii) most people die if their means of survival disappear, (iii) most people's access to the means of survival is contingent upon the political and economic systems where they live, which is to say that (iv) most people's actual survival is linked to the organization of the political and economic systems within which they live. These points, I think, are obvious, but all the more central for their obviousness. 
Trying to figure out how not to die - on behalf of yourself and others - requires technical-political reformatting and also an analysis of 'properly political' factors like power differentials between and among groups. The way life-support systems are organized is - no less than culture, politics, religion, or geography - a fundamental differentiating feature of human societies. The failure of the critical infrastructure zones that protect human life is not merely a worrisome edge case for rich countries. For about one in three people on the planet, the future societal collapse worried about by writers in rich countries is their present reality. The 2.2 billion people on Earth without safe drinking water, for example, already exist with one foot outside the zone of life extension maintained by infrastructure (UNICEF and WHO, 2019). Gupta points out that 'collapse', for rich countries, will mean not a zombie-movie apocalypse, but rather 'living in the same conditions as the people who grow your coffee' (Gupta, 2010b). Thinking about who controls the available means of survival is not just prudent in the case of coastal inundation from rising seas, the breakdown of global thermohaline circulation, or widespread crop failure. Starting with actual means of survival is to invite into political inquiry the set of questions that structure billions of human lives every morning.

The central and underexplored problem at the heart of rapid political and social transformation is that if you disassemble the interlocking technology stacks that support human life, many people will die because you have removed the ways they get calories, potable water, medical treatment, and heat. One piece of evidence that this problem is underexplored is that the histories, especially personal accounts, of revolutionary movements - no matter their ideological orientation - return time and again to water, toilets, food, and shelter (Bates, 2016). The question of how to reconfigure political and economic systems without also dismantling the lifesupport systems with which they're intergrown remains perennial. This task is made harder by the fact that forces that oppose revolutionary movements often create new conditions of necessity, either by direct violence or by restricting access to critical infrastructure. An alternative to existing life-support systems is necessary for revolutionary movements both because these movements require some measure of independence from existing systems and because such systems may be taken away or destroyed by the forces that control them. For much the same reason, new critical infrastructure systems must be made multiply redundant such can that they can survive attempts to eviscerate them.

Any plan for political and economic transformation, therefore, must start with a plan for taking care of basic human needs. Such a plan will have to be heavy on detail, light on handwaving, and offer a set of alternative technology stacks for keeping human beings alive so that they don't die when the standard systems of feeding and caring for them fail. It is unwise, unpredictable, and lethal to destroy or disable existing life-support systems without having first built alternatives. Converting to a new life-support system instead involves 'building a new one, prototyping it, bootstrapping it from the resources of the old, proving that it works, 
and then pulling the population across' (Gupta, 2013). As Bratton points out, stacks are 'intrinsically modular', so each is 'also a platform, and an interface even, for the redesign and replacement of the Stack-we-have with a Stack-we-want' (Bratton, 2015). Political theorists have taken as commonplace the idea that science and engineering are irreducibly political, that there is no neutral technical undertaking, and so forth. But this equation flows in reverse: to urge deep transformation without thinking through infrastructure is to neglect that engineering is embedded within politics.

Planning and assembling alternative life-support stacks changes the relationship between political struggle and infrastructure. As activists and thinkers come to live in partial but increasing independence from existing stacks, different tools, strategies, and modes of action become available to them, which engenders further political and technical actions that strengthen alternative stacks, which generates further political-economic space-opening, and so on. For example, in places like Catalonia and Valencia, New York City, Munich, and Mankosi, South Africa, community-run mesh networks among computers serve as a functional alternative to existing internet service providers (the author uploaded the article you are reading using one such network). These services use a decentralized network topology in which computers relay information between one another rather than through a centralized hierarchical structure controlled by an internet service provider. The email you send, rather than entering Comcast's fiber optic cables and running to a central point of control, bounces off your neighbor's roof, over to a Litebeam (which looks like a tiny satellite dish) on a laundromat roof and from there to an access point to the wider internet. In New York City, NYCMesh asks for donations of between $\$ 20$ and $\$ 50$ per month, though users who cannot pay do not have to (commercial providers in the area tend to charge about twice NYCMesh's suggested donation range). In Mankosi, Zenzeleni ('do it yourself' in isiXhosa) Community Networks offers vouchers to use the internet for a month for about $\$ 1.45$ USD in a country whose data rates are otherwise among the most expensive in the world (Malinga, 2019; Parkinson and Carelse, 2019). The rise of communitycontrolled mesh networks (i) demonstrates the technical viability of local experiments to create alternative stacks for internet access, communication, education, and so forth, and (ii) pulls developers, users, and capital from existing telecommunication stacks into community-owned ones, which creates the material, technical, and social means for further developments. It can be objected that telecommunications are not obviously a first-order element of a life-support stack. To be sure, sharing a file, pirating a paywalled academic paper, or checking email over a meshnet does not itself undo the interlocking of infrastructure and depredation, especially if the supply chains for your email service still brace against structures of degradation and exploitation. However, the sharing of information facilitates actions and systems that cause human beings to receive water or not, food or not, medical care or not. Telecommunications are necessary for running

(C) 2021 The Author(s), under exclusive licence to Springer Nature Limited. 1470-8914 Contemporary 187 Political Theory Vol. 21, 2, 175-197 
modern power networks, e.g. for linking up different distributed solar photovoltaic system into power-sharing grids, and for building resilient communities. Also, in practical terms, your alternative stack is probably not worth switching to if it does not offer a robust way to connect to the internet. It is true, however, that efforts to create alternative stacks require more services to be converted alongside telecommunications. This is why building alternative stacks for the production and transportation of energy, food, heat, and information that interleave with alternative telecom structures remains a crucial and self-reinforcing undertaking. For example, alternative systems for growing and distributing food remain essential to this project and offer their own histories of community-level innovation and political struggle. Ad hoc networks of community compost centers, vacant-lot gardens, vermicompost advice groups, guerilla vegetable planting, community food distribution programs, and so forth presently operate at wide but highly distributed scale, but can be scaled up and concentrated with the advent of new technologies (e.g. electric cargo bikes for low-carbon delivery of produce and food scrap collection, solar-powered compost aerators, vertical and indoor farming) and political tactics (e.g. 'survival pending revolution'-style initiatives modeled on the Black Panthers' Survival Programs). New York City, for example, hosts a number of compost centers, like the Red Hook Community Farms compost operation and the community compost program on the Lower East Side of Manhattan that are partially city-run and partially volunteer- and community-led. Volunteers at these sites gather and sort food waste, aerate windrows, and prepare finished compost for distribution. The Red Hook Community Farms compost yard in Brooklyn, NY, uses a solar-powered aerator to turn large windrows and runs entirely on lowcarbon energy. Compost from the Lower East Side is used, among other applications, by volunteers and LES Ecology Center workers to nourish street trees in lower Manhattan's dense streets, which provide natural protection against sun, heat, and airborne particulate matter and noise pollution from passing vehicles.

Developing alternative life-support stacks allows for a rethinking of, among other things, the value and purpose of separatism. The libertarian Right has long hosted 'preppers', people who practice a kind of consumerist self-sufficiency intended to guard against societal collapse. 'Prepping' for a coming apocalypse usually consists of buying canned goods, jugs of water, weapons, ammunition, first aid kits, flashlights, and so on, storing them on clip-shelving in a cabin or vacation home, and waiting for society to implode. Prepper websites tend to be both fanatical and carefully engaged with practical questions about the conditions for human survival, offering articles like ‘4 Ways To Preserve Food In A Solar Oven', 'My Off-Grid Water Solution', 'How to Make a Gas Cache', 'The Complete Guide to Foraging Wild Greens in North America', and 'How to Store Cooking Oil for the Long-Term' (Prepper Website, no date). Prepping in its present form largely exists as an individualist exercise in consumerism. Consider the work of the technopolitical collective Hermicity ('hermit city'), which envisions 'Small, sturdy, 
comfortable micro dwellings with electricity provided by the sun. Weekly deliveries of... fresh water and other necessities by drone... Decentralized technologies increasingly allow for decentralized living' (Pure, 2016). The Hermicity project is intensely interested in life-support systems and lacks prepping's embeddedness in right-wing politics, but remains unable to emerge from an atomized, quasiconsumerist model of disaster preparedness. The infrastructure history of separatist movements indicates that the primacy projects like Hermicity place on physical separation is potentially a mistake. It is likely more feasible, effective, and just to use those same techniques to develop a mesh of livability within current urban zones and with other people than to build an atomistic 'hermit city'. What would this sort of collectively-realized self-defense against dying look like and what would it require of those undertaking it? Such an effort would involve carving out spaces of autonomy not only in cultural or intellectual terrain, but also in the terrain of the physical world. Gorz offers the observation that the answer 'to the capitalist system is neither a return to the household economy and village autarky, nor the total, planned socialization of all activities: it consists, rather, in socializing the sphere of necessity... in order to reduce to a minimum, within everyone's life, what needs to be done, whether we like it or not' (Gorz, 2010).

Life-support infrastructure planning lies beyond understanding political contest as a 'radical' undertaking that one either has the gumption for or not. To understand a person's involvement in a given cause as a matter of their individual righteousness is to reproduce an especially disabling form of fundamental attribution error. Humans and the other animals - I am not aware of any exception to this - act with respect to the structures built inside and around them. More flexible, resilient, and efficient ways of producing and distributing food or information or energy, if they can be defended from attempts to disassemble them, can hollow out existing structures for meeting those needs. The presses of the Encyclopedia Britannica had nearly run for a quarter of a millennium before an open-source, free encyclopedia with essentially no paid editorial oversight called Wikipedia idled them in 36 months. The combined value of the four largest US coal producers fell from $\$ 34$ billion in 2011 to $\$ 0.15$ billion in 2015 in part because of changes in natural gas extraction, solar panel production, and wind turbine design (Houser and Marsters, 2016). Changes in information technology, materials science, and manufacturing procedures slowly but inexorably transform the terrain of political contest. Cheaper solar photovoltaic panels, for example, don't merely offer homeowners in Arizona the opportunity to reduce their electricity bills. They also offer a way to power a smartphone or lamp without ever connecting to a grid connected to a coal-fired plant - or to a specific arrangement of state power that controls that plant. Solar photovoltaic systems may power a neonatal health center in Somalia, allowing the hospital to reduce what it spends on electricity per month from $\$ 6,000$ to $\$ 30$ in a country with an average annual income of $\$ 482$ (UNFP, 2015).

(C) 2021 The Author(s), under exclusive licence to Springer Nature Limited. 1470-8914 Contemporary 189 Political Theory Vol. 21, 2, 175-197 
Independence from does not reduce to physical distance from. This fact is important to remember when developing an alternative life-support stack inside the space created by those that already exist. Separatist movements often overrate the emancipatory potential of physical separation and the capacity of physical distance from centers of political power to act as a shield from exploitation, domination, and despoliation. From the moment they have broken away and established a new settlement or autonomous zone, separatist movements have had to confront the fact of being infrastructurally, materially, hydrologically tied to the systems they were trying to escape. When a community's shortages become acute, distance can intensify, rather than weaken, these ties. The history of perhaps the best-known of these communities, The Farm, founded in 1971 on principles of nonviolence by about 300 hippies in Lewis County, Tennessee, is a parable about the centrality of infrastructure to alternative communities. The story of The Farm doesn't only involve 1970s counterculture and radical politics: its histories spend a surprising amount of time on two-burner Coleman stoves, sewage lines and giardia outbreaks, flour mills, kerosene lamps, 12 volt trickle charging, and slow-scan ham TV transmitters (Bates, 2016). A stroll around Zuccotti Park's mess hall, library, sanitation facilities, evolving patchwork of nylon shelters, rows of charging laptops and cell phones in the fall of 2011 underscored infrastructure's status as a central rather than peripheral concern for radical movements. Similar ad hoc kitchens and medical facilities sprung up during Black Lives Matter protests in the summer of 2020, reinforcing the indispensable nature of such interventions. These tactics of self-defense and self-reliance can only go so far, however, as long as they provision themselves from existing supply chains. As a matter of bare fact, most of the supplies found in Portland's BLM, NYC's Occupy, or Baltimore's uprising encampments are purchased around the corner at CVS, Giant, Target, or Duane Reade, using American credit cards linked to federally-insured bank accounts and so on. This is both understandable and unsurprising, and it is not evidence of hypocrisy or insufficient radicalism on the part of those who have set up these ad hoc medical and food support systems. Rather, it is a fundamental material reality that must be accounted for and overcome if such services and their provision are to move beyond temporary encampments.

This invites the question of whether the community-level interventions discussed here offer a vision that can be scaled up and expanded into a relatively featurecomplete alternative infrastructure stack. To be clear, this does not mean a withdrawal into eco-primitivist, decentralized communities that do not engage in large-scale commerce or social organization. There are important elements from decentralization or degrowth thinking inherent in the idea of alternative stacks, but the task of building an alternative infrastructure system does not by necessity entail communes, kibbutzim, and hand plows. As White writes (following but also partially departing from Bookchin), 'The counterculture vision of a decentralized ecological society... will have to give way to a more dynamic vision of 
postcapitalist democratic urbanscapes and ruralscapes that are constantly adjusting to, and making and remaking, their surrounding social ecologies' (Bookchin, 2004; White, 2008, 2016). The infrastructure-development side of this task is enormously complex and requires shifting the lived experience of the dominant technology stack versus its alternatives. A choice between

a. a carbon-intensive, high-consumption lifestyle in which you spend $>50 \%$ of your waking hours doing something you dislike so that you can afford to maintain your lifestyle until you become physically or mentally unable to continue and/or the system you've paid into collapses

or

b. a life in which your work is mostly non-coerced, you own fewer items but have access to many of the same amenities you'd otherwise have, plus cleaner air and water,

does not merely seem more appealing to many on a personal level: it creates space for the self-reinforcing development of alternative life support systems and moves political action away from the uncertain prospect of a 'revolution' that risks swapping one set of hierophants and control points for another.

When a critical mass of subareas (e.g. the domains whose overlap makes human survival possible) are covered by workable alternative infrastructures, older stacks may not need to be attacked. They may come to resemble the cavernous malls now tiling North America, empty because no one needs anything from them. Activists and engineers have been, with varying levels of intentionality, at work on viable alternative technology stacks for decades now. The broad base of advances in materials, manufacturing, energy delivery, computation, and so forth needed to supply the means for alternative stacks exist or are now coming into being. Gorz has argued that in the domain of software, "The battle between "proprietary software" and freeware represents' growing friction between technical systems that aim to take care of everyone's needs in a non-hierarchical, non-extractive manner and existing forms of meeting (or neglecting) basic needs. 'High-tech selfproviding equipment is rendering' the world industrial system that currently handles (some) people's basic needs, he argues, 'virtually obsolete' (Gorz, 2010). This is overstated but not incorrect. It undeniable that certain artistic, engineering, and political collectives, like the P2P Foundation, LIFE Camp, NYCMesh, Open Source Ecology, the LES Ecology Center, and so on are pushing at the edges of settled infrastructure space by developing alternative means of survival in their respective domains (Bauwens, 2016b, a). Open Source Ecology's Global Village Construction Set project, for example, aims to create open-source blueprints for low-cost versions of fifty industrial machines needed to replicate modern life: cement mixers, sawmills, bulldozers, seeders, well-drilling rigs, hay cutters, bakery 
ovens, microcombines, press forges, and so forth (Global Village Construction Set, 2020). This sort of basic and freely-available information democratizes and decentralizes the tools needed to build and maintain critical infrastructure services. Organizations like LIFE Camp in Queens, New York, work to reduce gun violence and create spaces of survival for those most likely to be killed by such violence. The work of LIFE Camp and other communities of care represents a direct intervention aimed at developing new means of not dying. Simply put, these groups aim to keep people alive who, as evidenced by epidemic levels of mortal violence, remain partially outside existing zones of livability established by the state. In the Netherlands, the P2P ('peer to peer') Foundation aims to develop an 'open knowledge commons' that builds the technical and organizational means for moving away from existing resource-extraction and intellectual property paradigms. Using commons-based standards for sharing information rather than exclusionary standards is not merely valuable for its own sake. As P2P argues, when 'naturally shareable goods are made artificially scarce... through legal repression or technological sabotage', the results can be 'particularly grievous for life-saving or planet-regenerating technological knowledge' (Bauwens, 2016b, a). Binding technical and scientific advances to processes of wealth accumulation doesn't merely deepen exploitation and inequality. It sequesters the tools needed to build a survivable future.

Note that a focus on infrastructure does not entail a commitment to technological determinism. For one, technological development and deployment do not lock in any one outcome. Rather, these processes are in constant exchange with economic currents, material flows, and political struggles. As Srnicek and Williams document, technological change is part of a shifting terrain on which political contests occur: 'The use of masks is met by new legislation against it; kettling is met by apps that track police movements; the recording of police violence is met by its criminalization; mass protest is met by heavy regulation that renders it boring and sterile; non-violent civil disobedience is met by violent police brutality. Political tactics are a dynamic field of forces, and experimentation is necessary in working around new state and corporate impediments to change' (Srnicek and Williams, 2015). What a newly-viable set of techniques can do, as one element among others in a shifting field of forces, is render courses of action more or less feasible. New capabilities can make possible arrangements of life that were previously unworkable. Gorz aspirationally describes how changes in the material and technological base of society make possible 'a future in which it will be possible to produce practically all that is necessary and desirable in cooperative or communal workshops; in which it will be possible to combine productive activity with learning and teaching, with experimentation and research... and with the invention of new forms and techniques of agriculture, building and medicine'. None of this is guaranteed to happen: ' $I$ do not say that these radical transformations will come about. I am simply saying that, for the first time, we 
can wish them to come about. The means exist, as well as the people who are methodically working toward their realization' (Gorz, 2010). The non-deterministic elements of this outlook are presaged by Winner's 1977 discussion of determinism in Marxism. 'Marx', Winner writes, suggests that 'each generation is strongly conditioned or informed by a technological inheritance that it in no sense "chose". While it is always possible that a particular generation might wish to review this inheritance, scrutinize the patterns that technics gives to life, and make new choices on the basis of this critique, such a procedure is not in fact something that occurs to anyone to do' (Winner, 2001). The argument of this article is in part that such a procedure is something that should occur to anyone to do. It is possible to agree about technological systems conditioning political and social life while disagreeing with the idea that 'the sociotechnical context into which we are born must simply be accepted as given' (Winner, 2001). Recognizing that technosocial terrain can be altered to enable more survivable futures is, in fact, one way of leaving a certain kind of determinism behind.

\section{Conclusion}

Critical infrastructure systems shape the possibility space for political action. Because of this fact, movements that wish to change society (especially movements that understand their work as revolutionary) should shift a significant amount of their focus and resources to building critical infrastructure systems that can serve as alternatives to existing infrastructure services. Often, movements whose success or failure has been understood in political or ideological terms, like Occupy Wall Street or The Farm in Lewis County, Tennessee, can be better understood in material and infrastructural terms. Being able to take care of everyone, which has often been understood as a goal or outcome of successful revolution or radical change, is better thought of as a condition for such change.

Theories, beliefs, and actions are mutually constituted by the feedback loops they share with one another. The braided loops that make them up are connected to changing social, political, and material conditions as both cause and effect. Different theories and forms of inquiry have different relationships to concrete outcomes in the world. Even if the nature of these differences is multilayered and ambiguous, theories' links with, situatedness within, and ability to alter broader political and material feedback loops remains relevant to the ways we evaluate theories themselves. Practical considerations operate at the core of even abstruse theoretical work and feedback loops continually turn over among abstraction, practice, and observation. Extending and reworking those feedback loops offers one way of linking theories and the worlds they are deployed in.

In much the same way, political and infrastructural processes are bound up together. Attempting to enact political and economic transformation without 
infrastructure support - without a way of pumping water, growing food, or delivering healthcare - is like doing origami with smoke. No matter how ambitious your scheme, how virtuosic your technique, the folds vanish as soon as you make them.

\section{Acknowledgements}

The author thanks L. Balfour, J. Bennett, Q. Lester, C. McNeil, T. Vasko, T. Wyatt, $\mathrm{S}$. Zhou, and two anonymous reviewers.

\section{About the Author}

Joseph Mohorčich is an assistant professor of political science at Lehman College, City University of New York, where he teaches courses in American politics, political philosophy, and science policy. He received his Ph.D. from Johns Hopkins University and has previously taught there and at Mannheim University.

\section{References}

Addie, J.-P. D. (2021) Urban life in the shadows of infrastructural death: From people as infrastructure to dead labor and back again. Urban Geography, pp. 1-13. https://doi.org/10.1080/02723638.2021. 1902633.

Addie, J.-P.D., Glass, M.R. and Nelles, J. (2020) Regionalizing the infrastructure turn: A research agenda. Regional Studies, Regional Science 7(1): 10-26. https://doi.org/10.1080/21681376.2019. 1701543.

Amin, A. (2013) Surviving the turbulent future. Environment and Planning D: Society and Space 31(1): 140-156. https://doi.org/10.1068/d23011.

Amin, A. (2014) Lively Infrastructure. Theory, Culture \& Society 31(7-8): 137-161. https://doi.org/10. 1177/0263276414548490.

Anand, N. (2017) Hydraulic City: Water and the Infrastructures of Citizenship in Mumbai. Durham: Duke University Press.

Anand, N., Gupta, A. and Appel, H. (eds.) (2018) The Promise of Infrastructure. Durham: Duke University Press.

Barry, J. (2012) The Politics of Actually Existing Unsustainability: Human Flourishing in a ClimateChanged, Carbon Constrained World. New York: Oxford University Press, USA.

Bates, A. (2016) Lifeboats: A Memoir. Mariposa Group. http://www.mariposagroup.org/thefarm.htm (Accessed: 7 January 2021).

Bauwens, Michel (2016) 10 Ways to Accelerate the Peer-to-Peer and Commons Economy, P2P Foundation, 3 October. https://blog.p2pfoundation.net/10-ways-accelerate-peer-peer-commonseconomy/2016/10/03 (Accessed: 7 January 2021).

194 (c) 2021 The Author(s), under exclusive licence to Springer Nature Limited. 1470-8914 Contemporary Political Theory Vol. 21, 2, 175-197 
Bauwens, Michael (2016) The Post-Capitalist Strategy of the P2P Foundation, Resilience. https://www. resilience.org/stories/2016-07-11/the-post-capitalist-strategy-of-the-p2p-foundation/ (Accessed: 7 January 2021).

Bennett, J. (2010) Vibrant Matter: A Political Ecology of Things. Durham: Duke University Press.

Bookchin, M. (2004) Post-scarcity Anarchism. 3rd. ed. Oakland, CA: AK Press (Working classics series, 3).

Boyer, D. (2018) Infrastructure, Potential Energy, Revolution. In N. Anand, A. Gupta and H. Appel (eds.) The Promise of Infrastructure. Durham: Duke University Press, pp. 223-244.

Bratton, B. H. (2015) The Stack: On Software and Sovereignty. Cambridge, Massachusetts: MIT Press (Software studies).

De Coss-Corzo, A. (2021) Patchwork: Repair labor and the logic of infrastructure adaptation in Mexico City. Environment and Planning D: Society and Space 39(2): 237-253. https://doi.org/10.1177/ 0263775820938057.

Dodson, J. (2017) The global infrastructure turn and urban practice. Urban Policy and Research 35(1): 87-92. https://doi.org/10.1080/08111146.2017.1284036.

Duneier, M. (2006) Ethnography, the ecological fallacy, and the 1995 Chicago heat wave. American Sociological Review 71(4): 679-688. https://doi.org/10.1177/000312240607100408.

Easterling, K. (2012) Lecture by Keller Easterling at CCA. California College of the Arts, November.

Easterling, K. (2014) Extrastatecraft: The Power of Infrastructure Space.; New York: Verso.

Eckersley, R. (2004) The Green State: Rethinking Democracy and Sovereignty. Cambridge, Mass: MIT Press.

Global Village Construction Set (2020) Open Source Ecology. https://wiki.opensourceecology.org/wiki/ Global_Village_Construction_Set. Accessed 7 Jan 2021.

Gorz, A. (2010) Ecologica. London; New York: Seagull Books.

Gupta, V. (2010a) Dealing in Security: Understanding Vital Services and How They Keep You Safe. http://resiliencemaps.org/files/Dealing_in_Security.July2010.en.pdf. Accessed 6 Jan 2021.

Gupta, V. (2010b) Time to Stop Pretending. The Dark Mountain Festival, Llangollen, Wales, 29 May. https://www.youtube.com/watch?v=EkQCy-UrLYw (Accessed: 6 January 2021).

Gupta, V. (2013) One Network One World - OHM2013. https://www.youtube.com/watch?v= 9CTCrWNYGTE. Accessed 10 June 2020.

Houser, T. and Marsters, P. (2016) The Hidden Cause of America's Coal Collapse. Rhodium Group, 22 February. https://rhg.com/research/the-hidden-cause-of-americas-coal-collapse/. Accessed 7 Jan 2021.

Johnson, S. (2006) The ghost map: The story of London's most terrifying epidemic-and how it changed science, cities, and the modern world. New York: Riverhead Books.

Jones, C.E. (ed.) (1998) The Black Panther party (reconsidered). Baltimore: Black Classic Press.

Klinenberg, E. (1999) Denaturalizing disaster: A social autopsy of the 1995 Chicago heat wave. Theory and Society 28(2): 239-295. https://doi.org/10.1023/A:1006995507723.

Lane, M. (2016) Political theory on climate change. Annual Review of Political Science 19(1): 107-123. https://doi.org/10.1146/annurev-polisci-042114-015427.

Larkin, B. (2013) The politics and poetics of infrastructure. Annual Review of Anthropology 42(1): 327-343. https://doi.org/10.1146/annurev-anthro-092412-155522.

MacArthur, J. and Matthewman, S. (2018) Populist resistance and alternative transitions: Indigenous ownership of energy infrastructure in Aotearoa New Zealand. Energy Research \& Social Science 43: 16-24. https://doi.org/10.1016/j.erss.2018.05.009.

Malinga, S. (2019) SA, Kenya among highest data prices in Africa, ITWeb. https://www.itweb.co.za/ content/DZQ58MVJEbgMzXy2 (Accessed: 3 July 2020).

McFarlane, C. and Rutherford, J. (2008) Political Infrastructures: Governing and Experiencing the Fabric of the City: Political infrastructures. International Journal of Urban and Regional Research 32(2): 363-374. https://doi.org/10.1111/j.1468-2427.2008.00792.x. 
Mitchell, T. (2011) Carbon Democracy: Political Power in the Age of Oil. New York: Verso.

NIOSH (2014) Coal Workers' Pneumoconiosis: Top 50 Counties with Highest Age-Adjusted Death Rates (Per Million Population), U.S. Residents Age 15 and over, 2000-2009, Work-Related Lung Disease Surveillance System (eWoRLD). https://wwwn.cdc.gov/eworld/Data/Coal_Workers_ Pneumoconiosis_Top_50_counties_with_highest_age-adjusted_death_rates_per_million_population_ US_residents_age_15_and_over_20002009/767 (Accessed: 15 December 2020).

Parkinson, C. and Carelse, V. (2019) The village that built its own wi-fi network, BBC News. https:// www.bbc.com/news/av/world-africa-47723967/internet-access-in-africa-are-mesh-networks-thefuture (Accessed: 3 July 2020).

Pasternak, S. and Dafnos, T. (2018) How does a settler state secure the circuitry of capital? Environment and Planning D: Society and Space 36(4): 739-757. https://doi.org/10.1177/0263775817713209.

Prepper Website | Preparedness • Survival • Alternative News (no date) Prepper Website. https://www. prepperwebsite.com/ (Accessed: 17 December 2020).

Pure, Y. (2016) Hermicity: Applications in Decentralized Living and Achieving Peak Emotion. Hermicity. https://zoomerjd.com/hermicity/hermicity_rainbow_paper.pdf (Accessed: 29 July 2016).

Salleh, A., Shiva, V. and Clark, J. (2017) Ecofeminism as Politics: Nature, Marx and the Post Modern. Second edition, this edition was published in 2017. London: Zed Books.

Schlosberg, D. (2005) Environmental Justice and the New Pluralism: The Challenge of Difference for Environmentalism. Oxford: Oxford University Press.

Schmidt, J. (2013) The empirical falsity of the human subject: New materialism, climate change and the shared critique of artifice. Resilience 1(3): 174-192. https://doi.org/10.1080/21693293.2013.837241.

Simone, A. (2004) People as Infrastructure: Intersecting Fragments in Johannesburg. Public Culture 16(3): 407-429. https://doi.org/10.1215/08992363-16-3-407.

Simone, A. (2015) Afterword: Come on out, you're surrounded: The betweens of infrastructure. City 19(2-3): 375-383. https://doi.org/10.1080/13604813.2015.1018070.

Springett, J. (2013) Stacktivism and the Means Not to Die From. (New Luddism panel at Immaterial Labour Isn't Working). youtube.com/watch?v=xXMQYha_8Dk (Accessed: 6 January 2021).

Springett, J. (2015) 'Seeing the Stack'. The Thought Menu, 2 April. http://opentranscripts.org/transcript/ seeing-stack (Accessed: 6 January 2021).

Srnicek, N. and Williams, A. (2015) Inventing the Future: Postcapitalism and a World Without Work. Brooklyn, NY: Verso Books.

Symons, J. and Karlsson, R. (2015) Green political theory in a climate-changed world: Between innovation and restraint. Environmental Politics 24(2): 173-192. https://doi.org/10.1080/09644016. 2015.1008252.

UNFP. (2015) A Solar-Powered Maternal and Neonatal Health Centre for Somalia, UNFPA Somalia. https://somalia.unfpa.org/en/news/solar-powered-maternal-and-neonatal-health-centre-somalia (Accessed: 7 January 2021).

UNICEF and WHO. (2019) Progress on Household Drinking Water, Sanitation and Hygiene 2000-2017: Special Focus on Inequalities. WHO/UNICEF, p. 138. https://www.who.int/water_sanitation_health/ publications/jmp-report-2019/en/ (Accessed: 30 June 2020).

US EIA. (2016) Form EIA-923 Detailed Data with Previous form Data (EIA-906/920). U.S. Energy Information Administration. http://www.eia.gov/electricity/data/eia923 (Accessed: 6 January 2021).

Vanderheiden, S. (2008a) Atmospheric Justice: A Political Theory of Climate Change. Oxford: Oxford University Press.

Vanderheiden, S. (ed.) (2008b) Political Theory and Global Climate Change. Cambridge, Mass: MIT Press.

White, D. (2008) Bookchin: A Critical Appraisal. London: Pluto Press.

White, D. (2016) Murray Bookchin's New Life. Jacobin, 11 July. https://jacobinmag.com/2016/07/ murray-bookchin-ecology-kurdistan-pkk-rojava-technology-environmentalism-anarchy/ (Accessed: 22 May 2021).

196 (c) 2021 The Author(s), under exclusive licence to Springer Nature Limited. 1470-8914 Contemporary Political Theory Vol. 21, 2, 175-197 
Winner, L. (2001) Autonomous Technology: Technics-Out-of-Control as a Theme in Political Thought. 9. Cambridge, Mass.: MIT Press.

Publisher's Note Springer Nature remains neutral with regard to jurisdictional claims in published maps and institutional affiliations. 